\title{
Concern for the Sobriety of Youth in Mtody Hufiec in 1927-1939
}

\begin{abstract}
Alcohol abuse among young people was a serious social problem in the interwar period. The aim of the article is to show how the Młody Hufiec magazine attempted to oppose the commonly accepted drunkenness of youth in Poland. The article describes actions undertaken in order to combat alcoholism and promote abstinence among youth, published by the magazine in 1927-1939.
\end{abstract}

Keywords: drunkenness, alcoholism, drug prevention, youth

\section{Introduction}

After Poland regained independence in 1918, broadly understood alcoholism was one of the most important and widespread social problems in Poland. Drinking alcohol was widely accepted in many circles, while drunkenness became part of the lifestyle of the residents of large cities, towns and villages. The acceptance of alcohol consumption in the culture of interwar Poland was rooted in social and historical context ${ }^{1}$. Alcohol production was very lucrative in the Kingdom of Poland in the mid-19th century and early 20th century $^{2}$. According to the sources, the compulsory consumption of alcohol from distilleries belonging to landowners, which was in force until the 19th century, forced every family

${ }^{1}$ BŁASZCZYK, J., „Walka Kościoła Katolickiego w walce z pijaństwem i alkoholizmem na łamach "Przewodnika Katolickiego" w latach 1930-1939”, Acta Universitatis Nicolai Copernici. Nauki Humanistyczno-Społeczne. Pedagogika. Z. 30, 2014.

${ }^{2}$ BISKUPSKI, J, Zapobieganie alkoholizmowi wśród dzieci i młodzieży w latach 1920-1939, [in:] R. MATUSIAK, K. SIGDA, K. KOZIOŁ (eds.), Zachowania ryzykowne dzieci i młodzieży-problemy wychowawcze uzależnienia, Lublin-Tarnów 2016, p. 43. 
of subjects to drink a certain amount of alcohol during a given year ${ }^{3}$. At that time, drinking alcohol to intoxication was a disgraceful habit. Moreover, it was believed that vod$\mathrm{ka}$ had medicinal and nutritional properties. According to the folk beliefs of the time, liquor offered sustenance and warmth, and what is more, people also believed that it calmed children ${ }^{4}$.

There is no doubt that drinking alcohol had a destructive effect not only on adults, but also on children and youth. This is evidenced by extensive research on alcoholism among the young generation carried out after World War $\mathrm{I}^{5}$. The first research, carried out immediately after the war was conducted by Fr. M. Sopoćko, whose work covered 1503 children, including 850 boys and 513 girls attending public elementary schools in Warsaw. Results showed that $68.5 \%$ of boys and $61.5 \%$ of girls drank alcohol, with vodka being the most "popular" choice among them 6 .

In 1931, a survey was carried out at the turn of May and June among youth studying at the University of Vilnius. The results showed that out of 385 students, 290 drank alcohol, 76 per cent of whom started using alcohol in secondary school, and 15 per cent at the university ${ }^{7}$.

During the interwar period, a number of initiatives were undertaken to promote the idea of abstinence, raise awareness of the important problem of alcohol abuse and its consequences, and even strive for the complete eradication of alcoholism ${ }^{8}$. The image of the concern for education in sobriety is reflected in numerous publications and articles in the periodicals and magazines available at that time, including Młody Hufiec, which is the subject of these considerations.

Among the various issues raised by priests, columnists, journalists and scouts of the Association of Polish Youth, much attention was paid to the fight against alcoholism among young people. The aim of the article is thus to show how Mlody Hufiec presented the impact of alcohol consumption on health, as well as the moral consequences of alcohol abuse, the idea that only a God-fearing Pole could effectively become a sober person, and how abstinence was promoted and encouraged.

3 BURSZTA, J., Społeczeństwo i karczma, Warsaw 1951, p. 10.

${ }^{4}$ CHWAlBA, J., (ed.), Obyczaje w Polsce. Od średniowiecza do czasów współczesnych, Warsaw 2008, p. 279.

5 BISKUPSKI, J., Zapobieganie alkoholizmowi, p. 43.

6 Świt, issue 275, 1927, p. 40.

7 Walka z Alkoholizmem, 1935, issue 25, p. 134.

${ }^{8}$ BISKUPSKI, J, Zapobieganie alkoholizmowi, p. 43. 


\section{Characteristics of the magazine}

Młody Hufiec was a magazine of the Union of Polish Youth and was published as a circular for the Catholic Association of Young Men in Poznań. In 1927, the Association of Polish Youth had more than 16 thousand members gathered in in 358 associations 9 It should be mentioned that the Association of Polish Youth was divided into men's organisation - the Catholic Association of Young Men, as well as women's organisation Catholic Association of Young Women ${ }^{10}$. It is assumed that the beginnings of the Catholic movement of non-school youth date back to the partitions, with the movement originating in the Poznań Archdiocese. The Catholic youth organisation was founded and supervised by priests ${ }^{11}$.

The period of establishment of the Association of Polish Youth dates back to the first years of the interwar period. In 1919, more precisely from 26th to 28th of February, a meeting of bishops' delegates from all dioceses took place in Warsaw. During the congress, temporary legislation was adopted and the first headquarters of a nationwide non-school youth organisation was established. The leadership was entrusted to Father Walerian Adamski and Father Ludwik Jarosz from Poznann ${ }^{12}$. During the Polish Episcopal Conference on the 12th of March 1919 in Warsaw, the bishops approved the resolutions adopted during the congress. As a result of these decisions, a meeting of youth associations secretaries from all over Poland was held in Poznan from the 25th of April to the 20th of May, led by Primate E. Dalbor ${ }^{13}$. It was then decided that all associations within a given voivodeship or diocese would form one organisation called the Union of the Associations of Polish Youth. Throughout Poland, all these unions had a leading organisation called the Union of the Associations of Polish Youth with a seat in Poznań ${ }^{14}$.

Thus, UAPY was a three-stage organisation, and these three levels of organisation can be characterised as follows:

1. Association of Polish Youth - the lowest level of the organisation. The area of activity of an Association was limited to the borders of the village, town, city district or parish. The Associations of Polish Youth were headed by a Board elected from among the youth during a general meeting. The Congress of Delegates and the Association Council were also in charge. The Associations comprised Polish

9 Sprawozdanie Związku Młodzieży Polskiej za rok 1927, Poznań 1928, p. 8.

${ }^{10}$ DMOWSKI, R. „Działalność Stowarzyszenia Młodzieży Polskiej w Diecezji Podlaskiej w latach 19191934”, Szkice Podlaskie 142006.

11 WILCZYŃSKI, L. „Katolickie Stowarzyszenia Młodzieży na Śląsku w okresie II Rzeczypospolitej”, Śląskie Studia Historyczno-Teologiczne 2002, vol. 32, issue. I, p. 137.

12 ADAMSKI, W., Zjednoczenie Młodzieży Polskiej. Kilka uwag o ustroju i działalności. Poznań 1926 p. 8 .

${ }^{13}$ GUZEWICZ, W., ,Stowarzyszenie Młodzieży Polskiej w międzywojennej diecezji łomżyńskiej w okresie II Rzeczypospolitej”, Saeculum Christianum 11 issue 22004.

14 KIEDOS, J., „Historia Związku Stowarzyszeń Młodzieży Polskiej na terenie diecezji katowickiej w latach 1922-1933”, Śląskie Studia Historyczno-Teologiczne 14, 1981. 
Catholic youth aged 14-25 $5^{15}$. Persons who exceeded the age of acceptance and who still wanted to remain in the Association were granted the title of supporting member of the organisation. The young people referred to each other as companions, and their common greeting - "Ready" - signified their readiness to fulfil their duties ${ }^{16}$.

2. The Union of Polish Youth - brought a number of Associations together. Their area of activity was limited by borders of a diocese and voivodeship. Membership was limited only to the Associations of Polish Youth. The aim of the Union was to facilitate and develop the work of the Associations. During the annual convention, delegates of the Associations elected the so-called Union Council, which in turn elected the Management Board. In 1926, there were 19 formally operating Unions in Poland, with four additional ones in the creation phase.

3. Union of Associations of Polish Youth - the organisation comprised the Unions of Polish Youth operating in the Republic of Poland. The aim of the organization was to issue regulations for itself, the Unions and the Associations. The supreme authority of the Union was the General Council, which comprised all representatives of the Unions ${ }^{17}$.

It must be said that Młody Hufiec was not the only magazine published by the Union of Polish Youth. The Union also published the Kierownik Stowarzyszeń Młodzieży magazine for the Boards of the Union of Polish Youth, Młoda Polka for members of the Associations of Polish Young Women, Przyjaciel Młodzieży for members of the Association and Młody Światek for school children. These magazines were published monthly, because the Association wanted to ensure that

all members could use them and that subscribing to them would not cause major financial difficulties ${ }^{18}$.

The first copy of Hufiec was published in January 1927 in Poznań. At that time, the editors of the paper wrote:

With that in mind, we give you the first issue of Młody Hufiec. We hope that it will show you the way and help you get your association work on the right track. In the time of concern and doubt, we hope that Młody Hufiec will be your best "friend" who will be able to make you smile"

The magazine was a continuation of an earlier association magazine, known as Doniesienia Zwiąku, which, among others:

\footnotetext{
15 ADAMSKI, W., op. cit., p. 10.

16 KIEDOS, J., op. cit., p. 241-242.

17 ADAMSKI, W., op. cit.

18 Sprawozdanie Zjednoczenia Młodzieży Polskiej, Poznań 1926, p. 14-15.

19 Młody Hufiec issue 1, 1927, p. 1.
} 
contained an ideological message, presented in an accessible form of a story, and presented the announcements from the Management Board ${ }^{20}$.

In 1926, the authorities of the Union of Polish Youth expressed the view that the Doniesienia magazine was very popular not only among the management boards, but also among the members of the organisation, who expressed their interest in the paper. Thus, the decision was made to develop and further improve the paper, introduce new content, change the name and layout. The 1926 report of the Association of Polish Youth presents the reasoning of this decision, as it was planned to

directly reach the members, influence them constantly, continuously, throughout the year, develop their interest in their own Associations and Unions ${ }^{21}$.

It was reported that the monthly magazine significantly contributed to an upturn in young people's work in the Catholic Association of Young Men. The importance of this message for the Association members is evidenced by the following passage:

With its always up-to-date articles regarding all areas of the association's work and activities, it constantly reminds us of it, it brings us up to speed and, above all, it stimulates us to work and be diligent in fulfilling our voluntary duties ${ }^{22}$.

The Hufiec magazine published articles outlining the organisation's activities, covered educational issues, and offered information on courses, conventions, meetings and initiatives organised in Poland, deemed by the Union to be useful for its members ${ }^{23}$. Among other important columns in the magazine were poems, short stories, varia and responses to letters were also important sections of the letter. The magazine reached numerous members of the Union of the Polish Youth, supporting young people and bringing them up in a spirit of patriotism and love for their country. In 1936, it was noted that

the issue was published in 10,000 copies and generated great interest in the field, both among the companions, as well as among the older generation of society and people outside the association $^{24}$.

It can be assumed that the articles in the magazine were written by older members of the organisation, because they were signed with the following names or nicknames: Komendant, Stary Druh, Wasz Druh, Starszy Druh, Druh Senior, Druh Nawrocki, Sędzia

${ }^{20}$ Jak pracują Stowarzyszenia Młodzieży Polskiej. Sprawozdanie Związu Młodzieży Polskiej w Poznaniu za rok 1926, Poznań 1927, p. 34

21 Ibidem, p. 35-36.

${ }^{22}$ Młody Hufiec issue 11 1936, p. 167.

23 Jak pracuja Stowarzyszenia Młodzieży Polskiej. Sprawozdanie Zwiazku Młodzieży Polskiej w Poznaniu za rok 1926, Poznań 1927, p. 34.

${ }^{24}$ Młody Hufiec issue 1 1937, p. 13. 
Druh, Wasz Grześ, Wasz byly prezes Franek, instruktor Zwiąkowy, Przyjaciel. Father Professor Kazimierz Michalski, Father Ludwik Jarosz and Lucjan Mazurkiewicz were responsible for supervising the paper, which numbered anywhere from 16 to 24 pages and included illustrations.

It should also be noted that every Association wishing to distribute the magazine among its members had to pay a quarterly subscription fee of 45 groszy. People who were not members of the organisation, as well as post offices, had to pay a higher fee, which amounted to 1.50 złoty.

The idea behind the name of the magazine was discussed in an article entitled "Nasz Młody Hufiec" ("Our Young Troop"), which was published in issue 4 in 1927. The article tells us that people are unable to live alone, and therefore they come together in societies, which have been described as troops. It was then considered that

a troop it is a tight-knit, uniform group of people who will act as soon as they hear an order or a call with all their collective power and effort. When we talk about a troop, we always think about some sort of order and obedience ${ }^{25}$.

In the following section, the author of the article focuses their thoughts on young people, whom they would like to become similar to valiant and noble troops of knights. The author then arguments for this position as follows:

Have you heard about knights and their troops? Even today, when they look at us from old paintings, dressed in hardened steel, looking at us their dangerous look, full of some sort of strange power, they inspire us, instilling admiration and reverence in us at the same time. Those knights, invincible in their struggles against the enemy, unbreakable and undefeatable by any means, were always ready to defend the faith and the church. Their hearts, imbued with passionate love of their homeland, were ready to make the greatest sacrifice for it [...] We want to see you, our dear companions, as such knights. You are supposed to be a good team of young people, like a knight troop. We want you to cultivate this masculine fortitude and power of will in your hearts, we want you to cultivate the ideas of truth and justice. Knightly righteousness of character should be a guarantee of your actions. Let us join our forces, connected by a common idea, one desire, let us become a troop of young knights of righteousness and truth ${ }^{26}$.

\section{Promoting sobriety}

Addressing the issue of abstinence among young people was one of the most important topics covered by the magazine. During the interwar period, efforts were made to organise activities aimed at promoting living in sobriety. An example of this was the celebration of the Sobriety Propaganda Weeks, which took place in the first days of February.

\footnotetext{
${ }^{25}$ Młody Hufiec issue 4, 1927, p. 57.

${ }^{26}$ Ibidem.
} 
In Młody Hufiec, we may find information published with the aim of inspiring members of the Association to participate in the Week:

We would simply like to encourage the Associations to join and support the activities of the Sobriety Propaganda Week Committees and to organise abstinence circles in the Associations. Let each Association have a lecture during one of its meetings on the fight against alcoholism, during which its disastrous consequences will be presented. ${ }^{27}$

On the occasion of this month's Sobriety Propaganda Week, you should join the ranks of those who have already took their stand against alcohol abuse - go out there and fight for the liberation of the Polish people from the clutches of alcohol ${ }^{28}$.

Each Sobriety Propaganda Week was preceded by a characteristic slogan, for example "Sobriety of all citizens - a necessity in our times"29, "Save the Youth" 30 . "Sobriety leads to Rebirth" 31 .

The magazine also called for organising and creating new abstinence clubs. This appeal was formulated as follows:

Establish Abstinence Clubs wherever possible. They should educate and bring up the apostles of sobriety, who will educate and lead Polish society towards sobriety ${ }^{32}$.

The abstinence clubs were to be established in every Association of Polish Youth. They were made up of young people who declared that they will

never take even a sip of beer or vodka ${ }^{33}$.

It is worth noting that in addition to the presented articles regarding promoting the Sobriety Week, the article titles themselves encouraged abstinence:

"Alcohol is our enemy", 34 "Sobriety - a need of our times" 35 "Sobriety as a source of moral and physical strength" $"$.

\footnotetext{
${ }^{27}$ Młody Hufiec 1931, p. 11.

${ }^{28}$ Młody Hufiec issue 2, 1934, p. 20.

${ }^{29}$ Młody Hufiec issue 2, 1934.

${ }^{30}$ Mtody Hufiec, 1937.

${ }^{31}$ Młody Hufiec issue 1, 1934.

32 Ibidem, p. 14.

${ }^{33}$ Mtody Hufiec 1927, p. 30.

${ }^{34}$ Młody Hufiec issue 2, 1928, p. 38.

${ }^{35}$ Młody Hufiec issue 1, 1934, p. 13-14.

${ }^{36}$ Młody Hufiec issue 2, 1939, p. 19.
} 
On the occasion of the Sobriety Propaganda Week, the monthly magazine promoted publications available on the publishing market, which referred to the phenomenon of alcohol addiction. Among the examples of such books listed by Hufiec were Dwa domy by A. Milkowska and Wróg rodziny by Father T. Gołdyński. The former was a story of two families, in which one is described as happy and the other as unhappy. The reason for this was rampant alcoholism in one family and sobriety in the other one. Another of the books concerned drinking alcohol in families, on the example of the writings by Father Jan Kapica - a well-known Silesian advocate for sobriety.

The concern for the sobriety of young people was also expressed through the publication of articles outlining the negative effects of abusing alcohol. These issues were presented as follows:

Alcohol is a terrible poison that handicaps energetic people, turns noble and lawful citizens into dirty egoists, talented and promising youth into hooligans, and well-behaved and pure people into rakes; alcohol is the destroyer of social, civic and family life - and thus one of humanity's most terrible enemies ${ }^{37}$.

Doctors tell us that the body is a miraculous machine, given to us by the Creator, so that we can eat food, talk, and so on. However, when a young man drinks vodka, beer or something similar, their bodies develop much worse than that. Such a young person is ill more often than somebody who does not drink. Frequent use of alcoholic beverages (vodka, wine and beer) can cause addiction $^{38}$.

Taking care of the graphic design, the magazine illustrated the content of the articles with a variety of graphic elements. They were supposed to underscore the message of the article and emphasise certain values that were important for the magazine. Characteristic illustrations referring to sobriety were presented, as exemplified in Figure 1 and Figure 2, presenting the title page of a 1934 issue of Młody Hufiec.

Figure 1 was a strong message for the readers of Młody Hufiec, which the authors probably realised because they did not leave any comments below. The symbolism of the image expresses the view that it is possible to choose between sober life and drinking, which leads to death.

The authors of the magazine shaped educational and patriotic attitudes and supported the society in maintaining abstinence with the illustrations they published. The messages published in Młody Hufiec magazine repeatedly emphasised that the Union of Polish Youth supported young people in their struggle with alcohol like St. George in the victorious dragon fight.

In the interwar period, the Catholic Church was an important institution promoting a healthy lifestyle. What is more, it was actively involved in sobriety campaigns. organised and presented lectures, sermons, radio broadcasts, as well as published books and oc-

\footnotetext{
37 Mtody Hufiec issue 1, 1934, p. 13.

${ }^{38}$ Młody Hufiec issue 2, 1928, p. 38.
} 


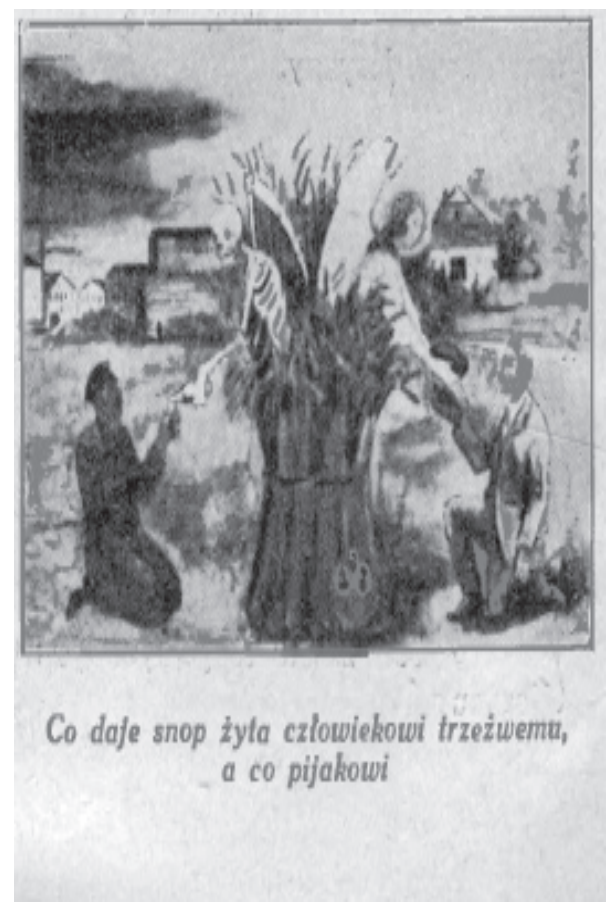

Fig. 1. (Młody Hufiec issue 2, 1934)

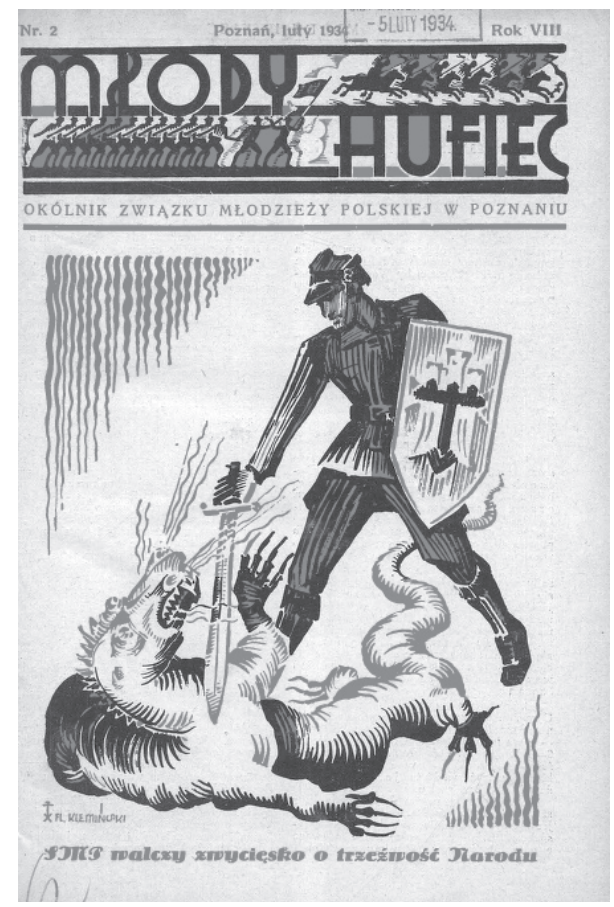

Fig. 2. (Młody Hufiec issue 2, 1934)

casional leaflets ${ }^{39}$. Clergy took an active part in Polish Anti-Alcohol Congresses, during which they gave lectures and presented their concerns regarding sobriety of young people $^{40}$. In addition, according to Jednodniówka published in 1936 on the occasion of the Sobriety Propaganda Week, there were Catholic anti-alcoholic movements ${ }^{41}$.

In February 1939, Młody Hufiec published an article entitled "Trzeźwość źródłem moralnej i fizycznej siły" ("Sobriety as a source of moral and physical strength"), which informed readers about the need to promote the idea of sobriety among young people associated in Catholic Youth Associations. The article said:

The Church expects us to become an invincible frontier of the spirit of Christ in Poland ${ }^{42}$.

39 BISKUPSKI, J, Zapobieganie alkoholizmowi; BŁASZCZYK, J., "Walka Kościoła Katolickiego w walce z pijaństwem i alkoholizmem na łamach "Przewodnika Katolickiego" w latach 1930-1939", Acta Universitatis Nicolai Copernici. Nauki Humanistyczno-Społeczne. Pedagogika. Z. 30, 2014.

40 Walka z Alkoholizmem, issue 25, 1935.

${ }^{41}$ It should be mentioned that anti-alcoholic movements in the interwar period included the Catholic Abstinent Association, the Polish Anti-Alcohol League, the Polish Association of Abstinent Priests, the Association of Abstinent Brotherhoods, the Association of Abstinent Teachers. See: W. PADACZ, "Katolicki ruch przeciwalkoholowy w Polsce odrodzonej”, Jednodniówka Katolickiego Koła Abstynentów, Warsaw 1936. p. $8-11$.

\footnotetext{
${ }^{42}$ Mtody Hufiec issue 2, 1939, p. 19
} 
Since alcohol abuse leads to more and more destruction and pain among the ranks of youth, leading them towards immorality and crime, we have to take a fervent action against alcoholism and become pioneers and educate the young generation on sobriety. This is what the Church and the State expect us to do. Where there is no sobriety, where drunkenness prevails, the spirit of Christ is also not there, and the Antichrist, crime, immorality, faithlessness and downfall prevail ${ }^{43}$.

In its messages, the magazine tried to promote a healthy lifestyle of girls and boys, promoting alcohol-free carnival balls and dancing parties. It is worth noting here that in the Second Republic of Poland, dancing was one of the regular pastimes of young adults, which took place at fire stations ${ }^{44}$ and outdoors in the summer ${ }^{45}$. Often, alcohol was drunk in large quantities, which led to arguments and fights between young men $^{46}$.

Examples of the concern for the sobriety of young people during dance parties can be found in Młody Hufiec issues from 1934 and 1935. Some of the fragments are particularly noteworthy:

We do not tolerate alcohol abuse - Our parties should be characterised by moderation, and preferably abstinence from alcohol, because during dancing parties in particular alcohol is the source of all evil, debauchery, fights and murder $^{47}$.

There are carnival parties organised in every town and even in every village. Demand that they are alcohol-free and boycott those parties where vodka will be sold despite your demands. Convince your parents, siblings, friends and acquaintances to express solidarity and to disdain entertainment that does not bring amusement, but instead become a source of decay, corruption and even crime. This will be the first step in the fight against the evil of alcohol. You will find out how much better it is to have fun without vodka, and you will bless those who have inspired you to be sober and to promote the principles of abstinence ${ }^{48}$.

The magazine also wrote that dancing and non-alcoholic parties for young people were in line with the Christian spirit. In 1936, the following information was published in issue no. 3 :

Hey! Our youth can have fun if they want it! And although no slofoxes, foxterriers or whatever the names of these black dances are were danced during any of these evenings, and even though

${ }^{43}$ Mtody Hufiec issue 2, 1937, p. 21

${ }^{44}$ OTTO W., "Wielkomiejskie życie Drugiej Rzeczypospolitej w polskim filmie fabularnym okresu międzywojennego. Wstęp do tematu”, Images 2013, issue 21-22, vol. 2, pp. 232.

${ }^{45}$ WOŹNIAK, A., "Przedmiejskie gry i zabawy. O czasie wolnym i świętowaniu na Gocławiu w dwudziestoleciu międzywojennym”, Etnografia Polska 2004, vol. XLVIII, issue.1-2.

${ }^{46}$ DURKA, J., Margines społeczny poludniowej Wielkopolski $w$ dwudziestoleciu międzywojennym w publicystyce Gazety Ostrzeszowskiej, [in:] Margines spoleczny w Drugiej Rzeczypospolitej, M. RODAK (ed.) Metamorfozy społeczne issue 6, Warsaw 2013, p. 77.

${ }^{47}$ Młody Hufiec issue 2, 1935, p. 21.

${ }^{48}$ Młody Hufiec issue 1, 1934, p. 14. 
there was no alcohol, everybody had great fun without insulting God, which can often be seen at alcohol-fuelled parties ${ }^{49}$.

\section{Conclusions}

Many of the texts regarding prevention of alcohol abuse published in periodicals and magazines of the interwar period were characterised by a great deal of concern for the sobriety of the nation. The problem of alcohol abuse among adults and young people in the Second Republic of Poland allowed the authors to more effectively fight in defence of abstinence and reach more people thanks to written word. It also seems that this was also facilitated by circumstances, because after 120 years of partitions, the publishers were no longer constrained by any anti-Polish censorship and could freely shape its publishing policy in terms of quantity and quality. ${ }^{50}$

In Młody Hufiec, the articles concerning the fight against alcohol abuse and promotion of sobriety among young people in 1927-1939 were strongly emphasised and aimed at celebrating values (for example patriotic or moral) which could help with persevering in abstinence. The magazine also depicted the disastrous consequences of drinking, concerning mental and physical dysfunction, decline of family values and addiction.

The authors also encouraged youth to join abstinence clubs, and promoted the notion that only a faithful Polish Catholic is a sober person.

\section{Works cited}

\section{Compilations}

BISKUPSKI, J., Karczma i alkohol w kulturze chłopskiej w Ślesinie i jego okolicach (od poczatku $X I X$ w. do lat 30. XX w.), [in:] Z problematyki etnograficznej Ślesina i okolic, E. JEGLIŃSKA (ed.), Ślesin 2012.

BISKUPSKI, J, Zapobieganie alkoholizmowi wśród dzieci i młodzieży w latach 1920-1939 [in:] Zachowania ryzykowne dzieci i młodzieży - problemy wychowawcze uzależnienia, R. MATUSIAK, K. SIGDA, K. KOZIOŁ (eds.), Lublin-Tarnów 2016.

BŁASZCZYK, J., "Walka Kościoła Katolickiego w walce z pijaństwem i alkoholizmem na łamach "Przewodnika Katolickiego" w latach 1930-1939”, Acta Universitatis Nicolai Copernici. Nauki Humanistyczno-Spoteczne. Pedagogika. Z. 30, 2014.

BURSZTA, J., Spoteczeństwo i karczma, Warsaw 1951.

CHWALBA, J., (ed.), Obyczaje w Polsce. Od średniowiecza do czasów wspótczesnych, Warsaw 2008.

49 Młody Hufiec, issue 3 1936, p. 46.

${ }^{50}$ PACIOREK, M., "Problematyka rozwoju polskiego czasopiśmiennictwa medycznego w latach międzywojennych ze szczególnym uwzględnieniem prasy higienicznej”, Medycyna Nowożytna 13/1-2, 2006. 
DMOWSKI, R. "Działalność Stowarzyszenia Młodzieży Polskiej w Diecezji Podlaskiej w latach 1919-1934", Szkice Podlaskie 142006.

DURKA, J., Margines społeczny południowej Wielkopolski $w$ dwudziestoleciu międzywojennym w publicystyce Gazety Ostrzeszowskiej, [in:] Margines społeczny w Drugiej Rzeczypospolitej, M. RODAK (ed.) Metamorfozy spoleczne vol. 6, Warsaw 2013.

OTTO W., "Wielkomiejskie życie Drugiej Rzeczypospolitej w polskim filmie fabularnym okresu międzywojennego. Wstęp do tematu", Images 2013, issue 21-22, vol. II Poznań.

PACIOREK, M., "Problematyka rozwoju polskiego czasopiśmiennictwa medycznego w latach międzywojennych ze szczególnym uwzględnieniem prasy higienicznej”, Medycyna Nowożytna 13/1-2, 2006.

WILCZYŃSKI, L. “Katolickie Stowarzyszenia Młodzieży na Śląsku w okresie II Rzeczypospolitej”, Śląsie Studia Historyczno-Teologiczne 2002, vol. 32, issue 1.

WOŹNIAK, A., "Przedmiejskie gry i zabawy. O czasie wolnym i świętowaniu na Gocławiu w dwudziestoleciu międzywojennym", Etnografia Polska 2004, vol. XLVIII, issue 1-2.

Sprawozdanie Zwiąku Młodzieży Polskiej-1927

Jednodniówka Katolickiego Kola Abstynentów z okazji Tygodnia Propagandy Trzeźwości - 1936.

Press

Młody Hufiec - 1927 (issue 2, issue 4), 1928 (issue 2), 1934 (issue 1, issue 2), 1935 (issue 2), 1936 (issue 3), 1937 (issue 1, issue 2), 1939 (issue 2).

Świt- 1927 (issue 275).

Walka z Alkoholizmem - 1935 (issue 25). 